\title{
Tuning the Surface Coating of IONs Toward Efficient Sonochemical Tethering and Sustained Liberation of Topoisomerase II Poisons [Corrigendum]
}

Michalkova H, Strmiska V, Kudr J, et al. Int $J$ on page 7621 is incorrect. The correct figures are shown Nanomedicine. 2019;14:7609-7624 below.

The authors have advised due to an error at the time of figure assembly, Figure 1D on page 7614 and Figure 6A
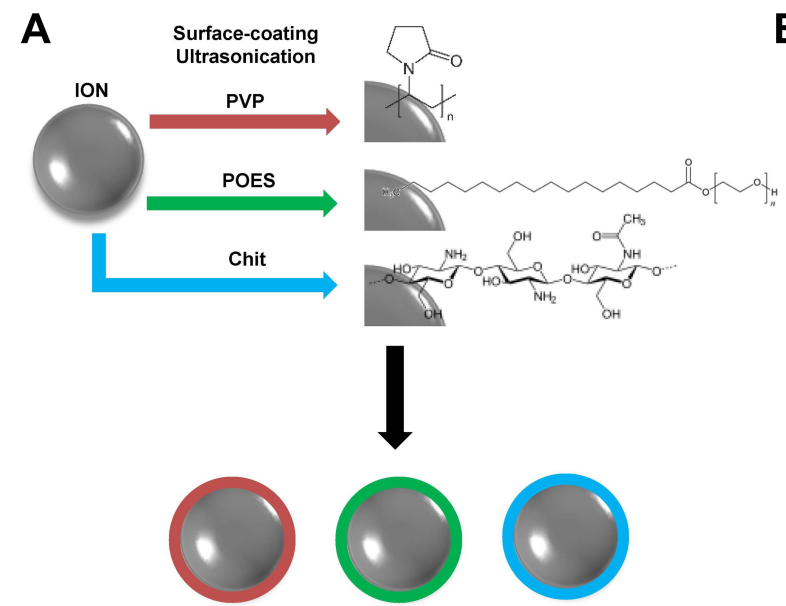

IONs-PVP

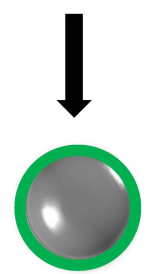

IONS-POES

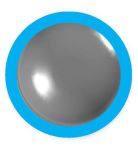

Drug complexation - incubation vs. ultrasonication
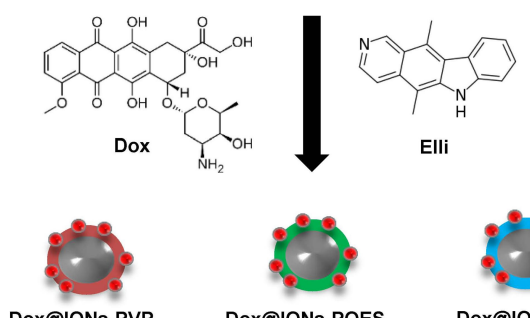

Dox@IONs-PVP
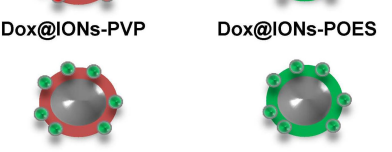

Elli@IONs-PVP

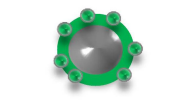

EIli@IONs-POES

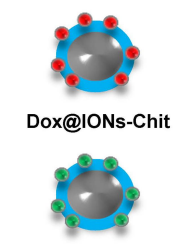

Elli@IONs-Chit
B

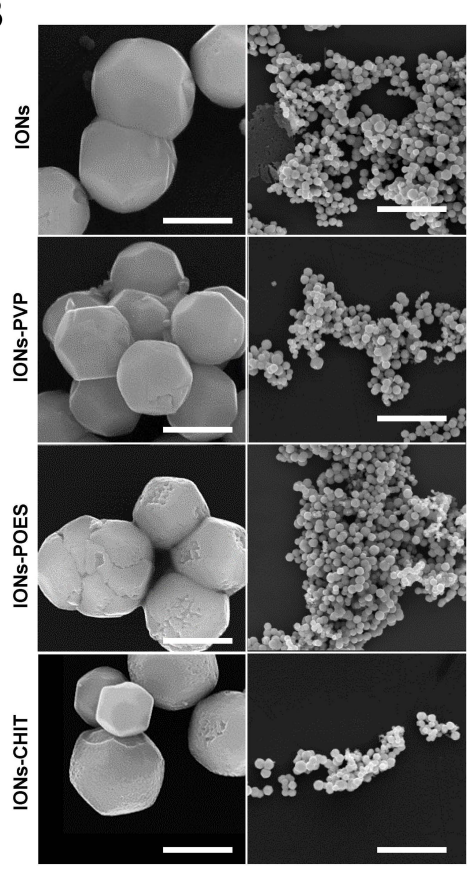

C

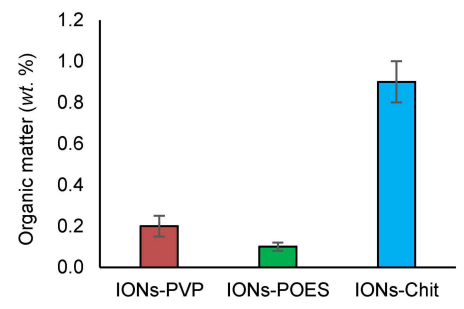

D
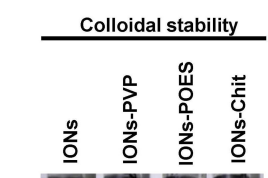

$\mathrm{Oh}$

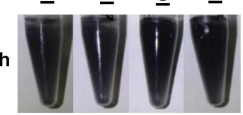

$6 \mathrm{~h}$

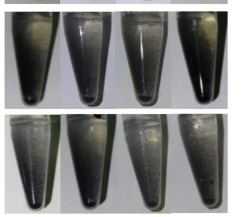

E $\rightarrow$ IONs $\rightarrow$ IONS-POES $\rightarrow$ IONS-PVP

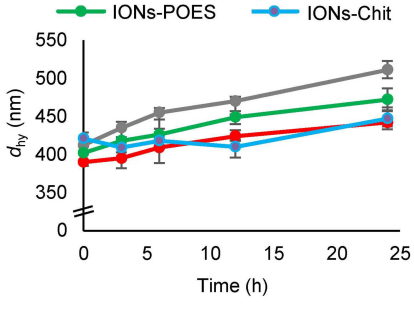

F $\rightarrow$ IONs $\rightarrow$ IONs-PVP

$\rightarrow$ IONs-POES $\longrightarrow$ IONs-Chit

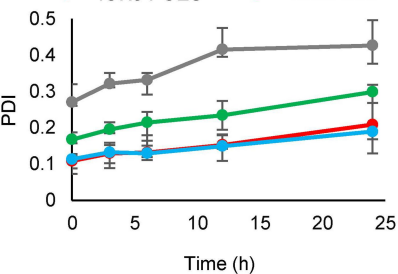

Figure I Surface coating of IONs with biocompatible surfactant (POES) or polymers (PVP and Chit). (A) Schematic representation of surface coating of bare IONs with PVP, POES and Chit with a consequent tethering of cytotoxic substances Dox and Elli using incubation or ultrasonication, respectively. (B) SEM micrographs of morphology of bare IONs and their morphology after surface coatings. The scale bars, $400 \mathrm{~nm}$ (left) or $5 \mu \mathrm{m}$ (right). (C) Content of organic matter in surface-coated formulations analyzed using CHNS/O analyzer. The values are expressed as the mean of three independent replicates $(n=3)$. Vertical bars indicate standard error. (D) Photodocumentation of a colloidal stability of bare and surface-coated IONs. Time-evolution of (E) dhy and (F) PDI, both analyzed in Ringer's solution. The values are expressed as the mean of six independent replicates $(n=6)$. The vertical bars + and - errors.

Abbreviations: IONs, iron oxide nanoparticles; POES, polyoxyethylene stearate; PVP, polyvinylpyrrolidone; Chit, chitosan; SEM, scanning electron microscopy; dhy, hydrodynamic diameter; PDI, polydispersity index.

submit your manuscript | www.dovepress.com
International Journal of Nanomedicine 2021:16 1707-1708

(c) (C) 2021 Michalkova et al. This work is published and licensed by Dove Medical Press Limited. The full terms of this license are available at https://www.dovepress.com/ (c) ${ }_{\text {BY }}$ NC terms.php and incorporate the Creative Commons Attribution - Non Commercial (unported, v3.0) License (http://creativecommons.org/licenses/by-nc/3.0/). By accessing the work you hereby accept the Terms. Non-commercial uses of the work are permitted without any further permission from Dove Medical Press Limited, provided the work is properly attributed. For permission for commercial use of this work, please see paragraphs 4.2 and 5 of our Terms (https://www.dovepress.com/terms.php) 

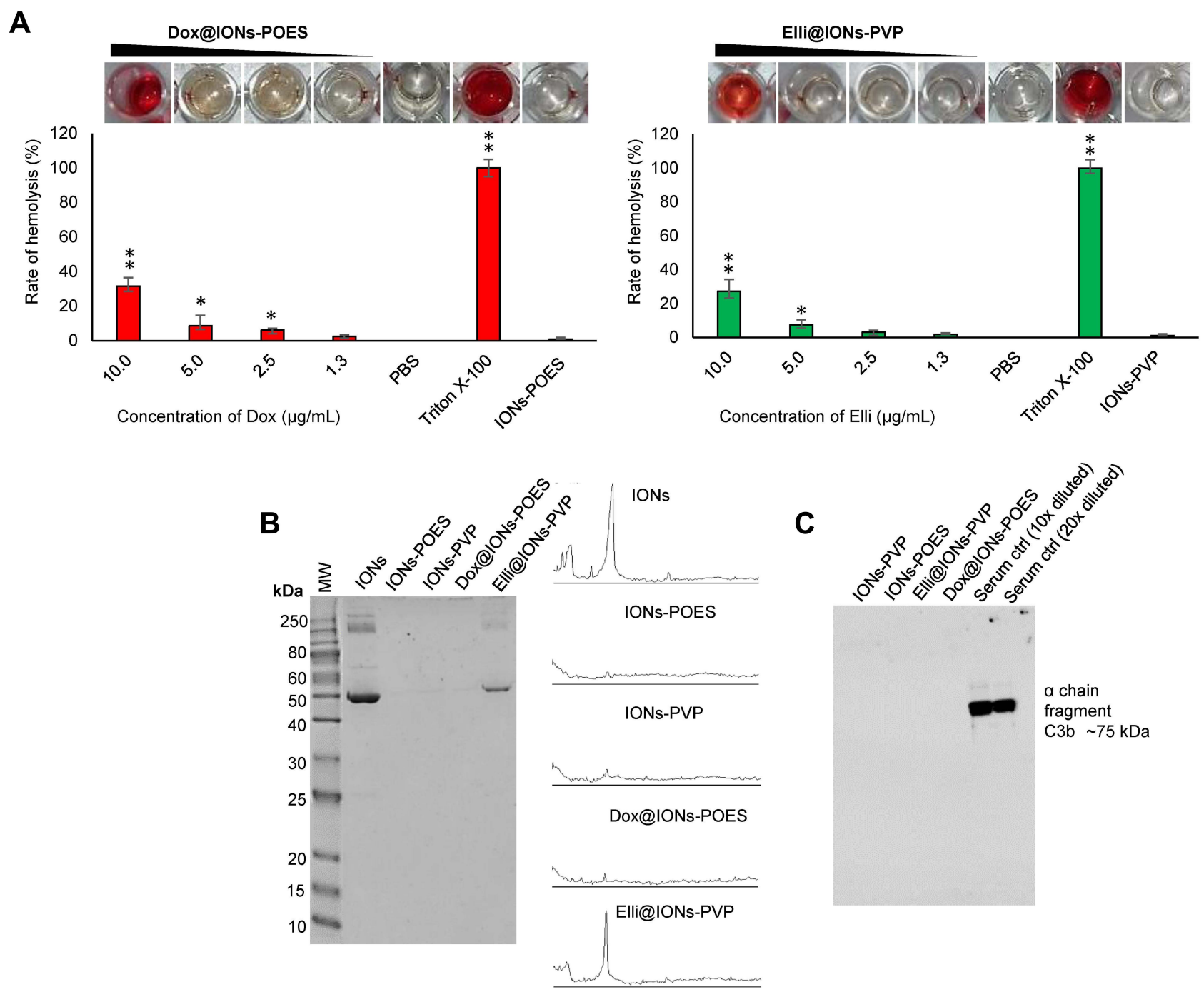

Figure 6 Examination of in vitro biocompatibility of Dox@IONs-POES and Elli@IONs-PVP. (A) Hemolysis of Dox@IONs-POES and Elli@IONs-PVP assayed on human RBCs. PBS ( $\mathrm{pH} 7.4$ ) and $0.1 \%$ Triton X-100 were utilized as negative and positive controls, respectively. Amount of tested IONs-POES and IONs-PVP without tethered Dox and Elli is adequate to the highest amount of IONs in Dox@IONs-POES and Elli@IONs-PVP treatments. Upper images depict representative photographs of tested samples. The values are expressed as the mean of three independent replicates $(n=3)$. Vertical bars indicate + and - errors. $* P<0.05$, $* * P<0.01$ related to the IONs-POES and IONs-PVP without tethered topo II poisons. (B) Protein corona patterns obtained after 30 mins incubation of annotated formulations with human plasma followed by extensive washing, elution, and loading onto I2\% SDS-PAGE. As a control, human plasma (I,000× diluted) was loaded to the first lane. Figures on the right side show protein coronas quantified by densitometric analysis. (C) Immunoblot of $\mathrm{C} 3 \mathrm{~b}$ binding from human serum from male $A B$ clotted whole blood.

Abbreviations: Dox, doxorubicin; Elli, ellipticine; IONs, iron oxide nanoparticles; RBCs, red blood cells.

The authors apologize for these errors and advise they do not affect the results of the paper.

\section{Publish your work in this journal}

The International Journal of Nanomedicine is an international, peerreviewed journal focusing on the application of nanotechnology in diagnostics, therapeutics, and drug delivery systems throughout the biomedical field. This journal is indexed on PubMed Central, MedLine, CAS, SciSearch ${ }^{\mathbb{B}}$, Current Contents ${ }^{\mathbb{B}} /$ Clinical Medicine, $^{2}$
Journal Citation Reports/Science Edition, EMBase, Scopus and the Elsevier Bibliographic databases. The manuscript management system is completely online and includes a very quick and fair peer-review system, which is all easy to use. Visit http://www.dovepress.com/ testimonials.php to read real quotes from published authors. 